\title{
PEMBERIAN PAKAN ALAMI Moina SP DENGAN DOSIS YANG BERBEDA TERHADAP PERTUMBUHAN (D3-D 21 ) LARVA IKAN PATIN SIAM (Pangasius hypoptalmus)
}

\section{Influence Of Natural Feed Moina sp. With A Different Dosage For The Growth (D3-D $\left.D_{21}\right)$ Of Larves Of Siamese Catfish (Pangasius hypoptalmus)}

\author{
Friem Exstrada $^{1}$, Indah Anggraini Yusanti ${ }^{1 *}$, Sumantriyadi $^{2}$ \\ ${ }^{1}$ Program Studi Ilmu Perikanan Fakultas Perikanan dan Kelautan Univ. PGRI Palembang \\ ${ }^{2}$ Program Studi Budidaya Ikan Fakultas Perikanan dan Kelautan Univ. PGRI Palembang \\ * Corresponding author: indahayusanti@gmail.com
}

\begin{abstract}
ABSTRAK
Ikan Patin Siam (Pangasius hypopthalmus) merupakan salah satu ikan unggulan di Sumatera Selatan yang memiliki nilai ekonomis tinggi. Dalam menyediakan benih yang berkualitas, tergantung dari perawatan larva yang baik. Salah satu factor utama dalam perawatan larva adalah kebutuhan pakan alami yang dimakan. Penelitian ini bertujuan untuk menguji efektifitas pemberian pakan alami Moina sp dengan dosis berbeda terhadap pertumbuhan dan sintasan larva ikan patin siam. Metode penelitian ini eksperimen dengan menggunakan Rancangan Acak Lengkap (RAL) dengan 4 taraf perlakuan dan 3 kali pengulangan dengan perlakuan pemberian pakan alami Moina sp P1 (15 ind/L), P2 (25 ind/L), P3 (35 ind/L), P4 (45 ind/L). Berdasarkan hasil uji statistik menunjukkan bahwa $\mathrm{F}_{\text {hit }}<\mathrm{F}_{\text {tab }}$ dimana pengaruh pemberian pakan alami Moina sp dengan dosis yang berbeda terhadap pertumbuhan panjang mutlak menunjukkan hasil tidak berpengaruh nyata, sedangkan hasil uji statistik menunjukkan bahwa $F_{h i t}>F_{\text {tab }}$ dimana pengaruh pertumbuhan bobot mutlak menunjukkan hasil berbeda sangat nyata. Parameter kualitas air pada pemeliharaan larva ikan patin siam menunjukkan nilai suhu $29,1^{\circ} \mathrm{C}-29,8^{\circ} \mathrm{C}, \mathrm{pH}$ yaitu $6,7-7,8$ dan DO berkisar $6,1-7,2 \mathrm{ppm}$.
\end{abstract}

Kata kunci : Ikan Patin Siam, Moina sp, Pakan Alami, Pertumbuhan, Sintasan.

\begin{abstract}
Siamese Catfish (Pangasius hypopthalmus) is one of the leading fish in South Sumatra which has high economic value. Providing quality seed depends on good larval care. One of the main factors in larvae care is the need for natural food that is eaten. The purpose of this study was to examine the effectiveness of natural feeding of Moina sp with different dosages on growth and survival of siamese catfish larvae. This research method was an experimental method using the Completely Randomized Design (CRD) with 4 treatment levels and 3 repetitions with treatment $P 1$ (15 ind/L), P2 ( 25 ind/L), P3 (35 ind/L), P4 (45 ind/L). Based on the results of statistical tests showed that $F_{\text {hit }}<F_{\text {tab }}$, where the effect of natural feeding Moina sp with different doses on the growth of absolute length showed the results had no significant effect, while the results of statistical tests showed that $F_{\text {hit }}>F_{\text {tab }}$, where the effect of feeding Moina sp with different doses on growth in absolute weight showed very significant different results and water quality parameters in the maintenance of siamese catfish larvae showed temperature of $29.1^{\circ} \mathrm{C}$ $-29.8^{\circ} \mathrm{C}, \mathrm{pH}$ of 6.7-7.8 and dissolved oxygen ranging from 6.1 - $7.2 \mathrm{ppm}$.
\end{abstract}




\section{Keywords: Siamese Catfish, Moina sp, Growth, Natural Feed, Survival Rate}

\section{PENDAHULUAN}

\section{Ikan Patin (Pangasius}

hypopthalmus) merupakan salah satu komoditas unggulan di Sumatera Selatan. Menurut Agriansa (2020), ikan patin yang berasal dari Sumatera Selatan merupakan salah satu pemasok ikan patin terbesar di Indonesia dengan total produksi pada tahun 2015 adalah 129.291.460 ton. Besarnya permintaan pasar domestik cukup tinggi dan cenderung meningkat dilihat dari jumlah produksi tahun 2017 sebesar 122.892 ton menjadi jumlah produksi 604. 587 ton pada tahun 2018 sehingga pemasok benih yang berkesinambungan sangat diperlukan untuk prospek persediaan benih Ikan Patin Siam (KKP, 2018).

Menurut Huwayono, dkk (2011), dalam menyediakan benih yang berkualitas maka perlu ditingkatkan pemberian pakan yang baik secara kualitas maupun kuantitasnya. Dari segi kualitas pakan ikan membutuhkan protein, vitamin, lemak, karbohidrat dan mineral, sedangkan dari segi kuantitasnya tergantung pada ketersediaan pakan yang cukup, apabila kekurangan pakan akan menghambat pertumbuhan dan menyebabkan tingkat mortalitas tinggi.

Dalam proses budidaya, pakan merupakan salah satu faktor terpenting yang berpengaruh terhadap pertumbuhan dan kelangsungan hidup ikan yang akan dibudidaya (Supriyan, 2020). Hal ini sesuai dengan pendapat Octo (2013) yang menyatakan bahwa pertumbuhan dan sintasan ikan patin siam pada fase larva merupakan permasalahan utama penyebab tingginya mortalitas yang disebabkan karena cadangan makanan berupa kuning telur sudah habis.

Pemberian pakan alami untuk mendukung pertumbuhan dan sintasan larva ikan patin siam diharapkan mampu memenuhi kebutuhan nutrisi larva ikan patin siam sehingga terhindar terjadinya kanibalisme yang berlebihan. Pakan alami yang digunakan harus yang ramah lingkungan dan mampu meningkatkan pertumbuhan dan sintasan pada stadia larva. Salah satu pakan alami yang berpotensi adalah Moina sp. Moina sp. merupakan kelompok udang renik yang termasuk dalam filum Crustacea dan sub ordo Cladocera. Ukuran Moina sp. berkisar 500-1.000 $\mu \mathrm{m}$ sangat cocok digunakan sebagai pakan awal larva ikan karena ukurannya sesuai dengan bukaan mulut larva ikan (Mudjiman, 2008 dalam Prastiwi, 2016).

Pemanfaatan pakan alami Moina sp sebagai pakan ikan telah dilaporkan dalam beberapa penelitian, diantaranya penelitian yang dilakukan oleh Rahmah, $d k k$ (2012), mengenai penggunaan pakan alami Moina sp dengan dosis berbeda pada larva ikan baung yang menghasilkan panjang mutlak $0,9 \mathrm{~cm}$ dan tingkat kelangsungan hidup sebesar 90\%. Selain itu penelitian yang dilakukan Prastiwi (2016), mengenai pemberian pakan alami Moina sp yang diperkaya tepung ikan pada larva ikan lele dengan konsentrasi terbaik yaitu 6 gr/l memberikan pertumbuhan berat mutlak sebesar 0,25 gr, pertumbuhan panjang sebesar $2,3 \mathrm{~cm}$ dan sintasan sebesar $98 \%$. Untuk itu perlu dilakukan penelitian mengenai pemberian pakan alami Moina sp terhadap larva ikan patin siam (Pangasius hypopthalmus), khususnya pada stadia larva $\mathrm{D}_{3}$ hingga $\mathrm{D}_{21}$. 


\section{METODE PENELITIAN \\ Waktu dan Tempat}

Penelitian dilakukan pada bulan

Juni hingga Juli 2020 pada Stasiun

Perbenihan Bidang Perikanan Budidaya,

Dinas Kelautan dan Perikanan Provinsi

Sumatera Selatan di Desa Air Satan

Kecamatan Muara Beliti Kabupaten Musi

Rawas.

\section{Alat dan Bahan \\ Alat yang digunakan dalam penelitian ini yaitu akuarium, timbangan digital, aerator, termometer, $\mathrm{pH}$ meter, sedangkan bahan yang digunakan adalah larva ikan patin siam dan Moina sp.}

\section{Metode Penelitian}

Penelitian ini menggunakan

Rancangan Acak Lengkap (RAL) dengan 4 taraf perlakuan dan 3 ulangan dengan perlakuan sebagai berikut :

P1 : Pakan alami Moina sp 15 ind/L

P2 : Pakan alami Moina sp 25 ind/L

P3 : Pakan alami Moina sp 35 ind/L

P4 : Pakan alami Moina sp 45 ind/L'

\section{Parameter Pengamatan}

\section{Pertumbuhan Panjang Bobot}

Perhitungan pertumbuhan panjang dengan rumus yang mengacu pada Effendie (1997), yaitu :

$$
\mathbf{P m}=\mathbf{L t}-\mathbf{L o}
$$

\footnotetext{
Keterangan :

$\mathrm{Pm}=$ Pertumbuhan panjang mutlak $(\mathrm{cm})$

Lt = Panjang rata-rata Ikan pada akhir penelitian $(\mathrm{cm})$

Lo = Panjang rata-rata Ikan pada awal penelitian $(\mathrm{cm})$
}

Perhitungan bobot mutlak dilakukan dengan rumus yang mengacu pada Effendie (1997) dengan menggunakan timbangan digital sebagai berikut :

$$
\mathbf{W}=\mathbf{W t}-\mathbf{W o}
$$

Keterangan :

$\mathrm{W}=$ Pertambahan berat rata-rata (gram)

$\mathrm{Wt}=$ Berat rata-rata Ikan pada akhir penelitian (gram)

Wo $=$ Berat rata-rata Ikan pada awal penelitian (gram)

Kelangsungan Hidup

Kelangsungan hidup atau sintasan dihitung dengan rumus yang mengacu Effendie (1997) sebagai berikut:

$$
\mathrm{SR}=\frac{\mathrm{Nt}}{\mathrm{No}} \times 100 \%
$$

Keterangan :

SR = Survival Rate (sintasan)

$\mathrm{Nt}=$ Jumlah larva akhir pengumpulan data

No = Jumlah larva awal pengumpulan data

\section{Kualitas Air}

Data kualitas air yang dianalisis meliputi Suhu, DO dan $\mathrm{pH}$.

\section{HASIL DAN PEMBAHASAN}

Berdasarkan penelitian yang telah dilakukan, diperoleh hasil rata-rata pertumbuhan panjang larva ikan patin siam dengan pemberian pakan alami Moina sp pada pengamatan $\mathrm{D}_{3}$ hingga $\mathrm{D}_{21}$ seperti yang disajikan pada Gambar 1 berikut ini. 


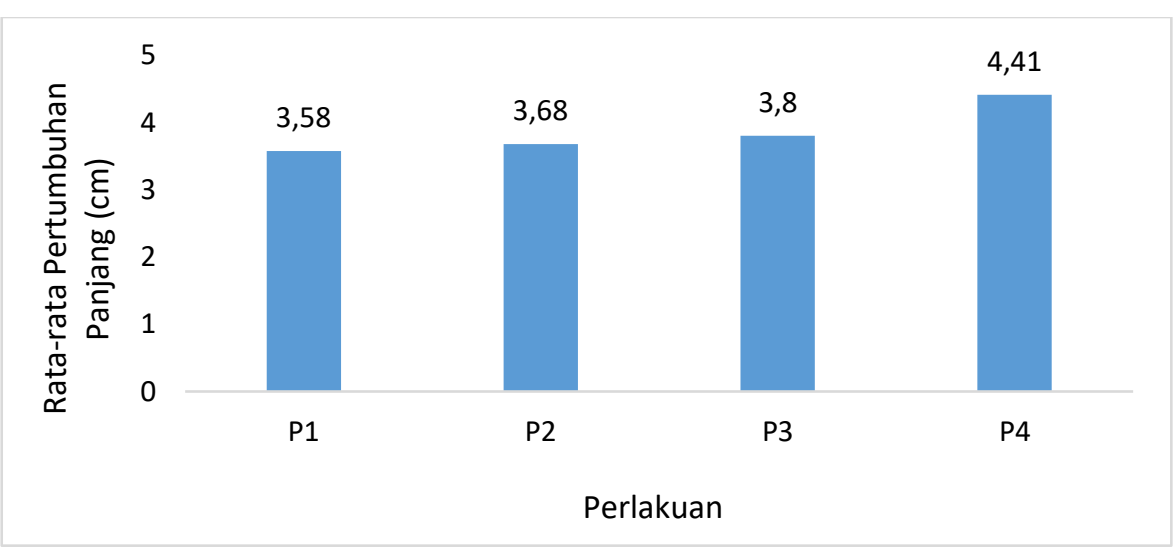

Gambar 1. Rata-rata Pertumbuhan Panjang Larva Ikan Patin Siam

Dari Gambar 1 dapat dilihat bahwa perlakuan $\mathrm{P} 4$ yaitu pemberian pakan alami Moina sp sebanyak 45 ind/L menghasilkan rata-rata pertumbuhan panjang larva ikan patin siam yang tertinggi yaitu sebesar $4,41 \mathrm{~cm}$ dibandingkan dengan perlakuan lainnya. Hal ini diduga karena pakan yang diberikan memenuhi kebutuhan ikan untuk tumbuh dan beradaptasi, dimana semakin banyak dosis yang diberikan maka semakin baik pertumbuhannya. Hal ini didukung oleh pendapat Anggraeni dan Nurulita (2013) yang menyatakan bahwa nutrien yang dimanfaatkan dikonversikan menjadi energi yang digunakan untuk metabolisme dan pergantian bagian tubuh sel yang rusak.

Pada fase larva, ikan patin siam membutuhkan asupan energi lebih banyak dibandingkan ikan patin siam dewasa. Hal ini sesuai pernyataan Mahyudin (2010) yang menyatakan bahwa semua jenis ikan memiliki laju metabolisme bobot tubuh yang akan semakin menurun seiring dengan bertambahnya ukuran ikan tersebut. Ikan yang berukuran kecil (larva) mengkonsumsi lebih banyak makanan karena laju pertumbuhannya lebih pesat.
Selanjutnya diikuti perlakuan P3 (pakan alami Moina sp 35 ind/L) dengan nilai sebesar $3,80 \mathrm{~cm}, \mathrm{P} 2$ (pakan alami Moina sp 25 ind/L) sebesar 3,68 cm dan perlakuan P1 (pakan alami Moina sp 15 ind/L) sebesar 3,58 cm menunjukkan nilai terendah dibandingkan dengan perlakuan lainnya, hal ini di duga disebabkan jumlah pakan yang diberikan lebih sedikit dari perlakuan P4. Pakan yang diberikan diduga dimakan, diserap dan digunakan untuk bergerak, adaptasi dan sisanya digunakan untuk tumbuh sehingga pertumbuhannya kurang maksimal. Selain itu, sifat larva ikan patin siam yang selalu bergerak menyebabkan proses pencernaan dan pengosongan lambung yang lebih cepat.

Berdasarkan hasil uji statistik ANOVA menunjukkan bahwa $\mathrm{F}_{\text {hit }}<\mathrm{F}_{\text {tab }}$, yang mengindikasikan pemberian pakan alami Moina sp dengan dosis yang berbeda terhadap rata-rata pertumbuhan panjang mutlak larva ikan patin siam memberikan pengaruh tidak nyata. Hasil pemeliharaan larva ikan patin siam diperoleh data rata-rata pertumbuhan bobot mutlak yang disajikan pada Gambar 2 berikut ini: 


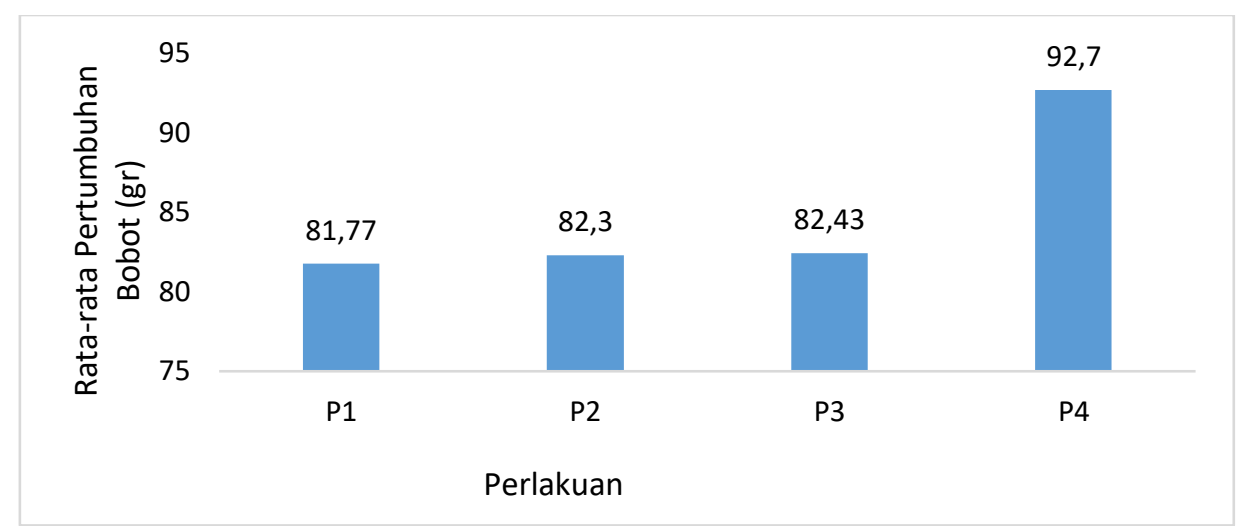

Gambar 2. Rata-rata Pertumbuhan Bobot Larva Ikan Patin Siam

Pada Gambar 2 diperoleh nilai tertinggi rata-rata pertumbuhan bobot larva ikan patin siam pada perlakuan P4 yaitu pemberian pakan alami Moina sp sebanyak 45 ind/L sebesar 92,7 gram, tingginya nilai tersebut diduga karena larva ikan patin siam yang diberikan pakan alami Moina sp mempengaruhi pertumbuhan larva sehingga kandungan nutrisi pada pakan alami tersebut menjadi kebutuhan dalam proses terjadinya pertumbuhan. Selanjutnya diikuti perlakuan P3 (pakan alami Moina sp 35 ind/L) dengan nilai sebesar 82,43 gram , P2 (pakan alami Moina sp 25 ind/L) sebesar 82,30 gram, dan yang terendah pada perlakuan P1 (pakan alami Moina sp $15 \mathrm{ind} / \mathrm{L})$ sebesar 81,77 gram.
Berdasarkan hasil uji statistik menunjukan bahwa $F_{\text {hit }}>F_{\text {tab }}$, dimana pengaruh pemberian pakan alami Moina sp dengan dosis yang berbeda terhadap pertumbuhan bobot mutlak menunjukkan hasil berbeda sangat nyata, hal ini diduga karena jumlah pakan yang diberikan mendekati daya tampung lambung sehingga pakan alami Moina sp yang diberikan dapat dikonsumsi dan dicerna sempurna oleh larva ikan patin siam. Hal ini sesuai dengan pendapat Srichanun, $d k k$ (2011), yang menyatakan bahwa proses pencernaan larva melalui kontribusi aktifitas enzim tripsin, chymotrypsin dan amylase yang terdapat pada pakan hidup, salah satunya Moina sp memiliki peranan penting terhadap pertumbuhan ikan.

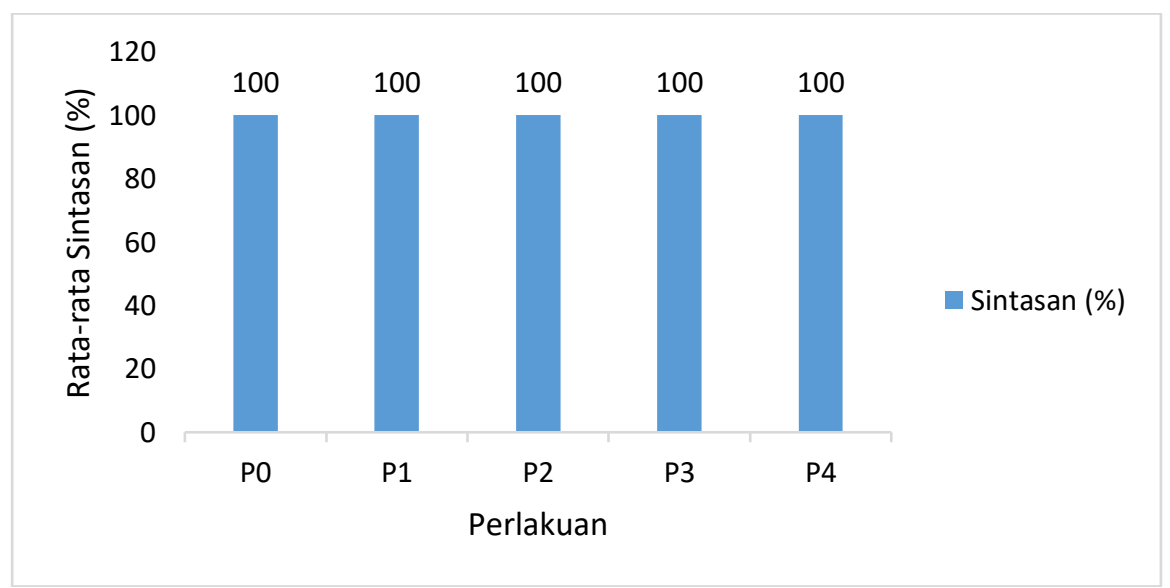

Gambar 3. Rata-rata Sintasan Larva Ikan Patin Siam 
Berdasarkan Gambar 3. sintasan larva ikan patin siam pada semua perlakuan sampai akhir penelitian menunjukkan nilai sintasan sebesar $100 \%$, hal ini diduga karena tingkat persaingan makanan dan kondisi lingkungan mendukung pemeliharaan sehingga asupan pakan alami Moina sp dimanfaatkan oleh ikan patin siam secara efektif. Pernyataan tersebut didukung oleh oleh Nugroho (2015) dalam Raharjo, $d k k$ (2016) yang menyatakan bahwa besar kecilnya nilai sintasan dipengaruhi oleh kondisi pemeliharaan ikan yang meliputi kualitas air, padat tebar dan komposisi yang terdapat dalam pakan tersebut. Berdasarkan hasil uji statistik ANOVA diperoleh bahwa $F_{\text {hit }}<F_{\text {tab }}$ yang mengindikasikan pemberian pakan alami Moina sp dengan dosis yang berbeda terhadap sintasan larva Ikan Patin Siam memberikan pengaruh tidak nyata.

Hasil pengamatan kualitas air selama penelitian diperoleh nilai suhu berkisar antara $29,1{ }^{\circ} \mathrm{C}$ hingga $29,8{ }^{\circ} \mathrm{C}$. Diduga nilai suhu ini sesuai untuk pertumbuhan dan kelangsungan hidup larva ikan patin siam. Hal ini mengacu pada pendapat Yuli (2017) yang menyatakan bahwa kisaran suhu optimal untuk budidaya ikan patin siam (Pangasius hypopthalmus) adalah antara $27^{\circ} \mathrm{C}$ hingga $32^{\circ} \mathrm{C}$. Untuk pengamatan $\mathrm{pH}$ didapatkan nilai $\mathrm{pH}$ sebesar 6,7 hingga 7,8 . Nilai $\mathrm{pH}$ ini termasuk $\mathrm{pH}$ yang optimal untuk budidaya ikan patin siam. Pendapat tersebut didukung oleh Kordi \& Tancung (2007), yang menyatakan bahwa $\mathrm{pH}$ yang cocok untuk ikan patin siam (Pangasius hypophthalmus) adalah 6,5 hingga 9,0 . Se sebaliknya menurut Effendie (2003) dalam Haris (2018), menegaskan bahwa jika nilai $\mathrm{pH}$ rendah akan menyebabkan pertumbuhan ikan terhambat dan ikan rentan terkena bakteri dan parasit, bahkan bisa terjadi kematian pada ikan. Sedangkan untuk pengamatan oksigen terlarut didapatkan nilai berkisar antara 6,1 hingga 7,2. Nilai tersebut, menurut Sastrawijaya (2000) dalam Haris (2019) termasuk dalam batas toleransi bagi organisme akuatik, karena kandungan oksigen terlarut untuk kehidupan organisme akuatik minimal 5 mg/l. Siagian (2009) dalam Ramadhan (2020) menambahkan bahwa kandungan oksigen terlarut sangat berperan bagi organisme di perairan untuk proses oksidasi nutrien yang masuk ke dalam tubuh.

\section{KESIMPULAN}

Berdasarkan penelitian yang telah dilakukan, disimpulkan bahwa pemberian pakan alami Moina sp memberikan pengaruh terhadap pertumbuhan panjang mutlak dan bobot mutlak tertinggi pada pada perlakuan $\mathrm{P} 4$ pemberian (pakan Moina sp sebanyak 45 ind/L) dengan nilai rata-rata $4,41 \mathrm{~cm}$ dan 92,7 gram. Sedangkan pengujian parameter kualitas air diperoleh nilai yang mendukung kegiatan untuk pertumbuhan larva ikan patin siam.

\section{DAFTAR PUSTAKA}

Agriansa, L., Sumantriyadi, S., dan Sari., L.P. 2020. Analisis Budidaya Pembesaran Ikan Patin (Pangasius sp.) Di Kecamatan Talang Kelapa Kabupaten Banyuasin. Jurnail-Ilmu-ilmu Perikanan dan Budidaya Perairan. Vo.15(1) : 10-20. DOI : http://dx.doi.org/10.31851/jipb p.v15i1.4295

Anggraeni., dan Nurulita A. 2013. Pengaruh Pemberian Pakan Alami dan Pakan Buatan Terhadap Pertumbuhan Ikan Betutu (Oxyeleotris marmorata) 
Pada Skala Laboratorium. Jurnal Sains dan Seni. Vol. 2 (2) : 17-26. DOI: $10.12962 / \mathrm{j} 23373520 . \mathrm{v} 2 \mathrm{i} 2.4$ $\underline{067}$

Dewi, A. T., Suminto, S., dan Nugroho, R. A. 2019. Pengaruh Pemberian Pakan Alami Moina Sp. Dengan Dosis Yang Berbeda Dalam Feeding Regime Terhadap Pertumbuhan Dan Kelulushidupan Larva Ikan Baung (Hemibagrus Nemurus). Jurnal Sains Akuakultur Tropis. Vol.3(1) : 17-26. DOI : https://doi.org/10.14710/sat.v3i1. $\underline{3267}$

Effendie, M. I. 1997. Biologi Perikanan. Yayasan Pustaka Nusatama. Yogyakarta.

Haris, R.B.K., dan Yusanti, I.A. 2018. Studi Parameter Fisika Kimia Air Untuk Keramba Jaring Apung Di Kecamatan Sirah Pulau Padang Kabupaten Ogan Komering Ilir Provinsi Sumatera Selatan. Jurnal Ilmu-ilmu Perikanan dan Budidaya Perairan. Vol.14(2). HIm : 57-62. DOI: http://dx.doi.org/10.31851/jipbp. v13i2.2434

Haris, R.B.K., dan Yusanti, I.A. 2019. Analisis Kesesuaian Perairan Untuk Keramba Jaring Apung Di Kecamatan Sirah Pulau Padang Kabupaten Ogan Komering Ilir Provinsi Sumatera Selatan. Jurnal Lahan Suboptimal. Vol. 8 (1). Hlm : 20-30. DOI: https://doi.org/10.33230/JLSO.8. $\underline{1.2019 .356}$

Huwoyono, G., Suhenda, N., dan Nugraha. 2011. Pembesaran Ikan Baung (Hemibagrus Nemurus) yang Diberi Pakan Berbeda Dikolam Tanah. Berita Biologi. Vol 10 (4) : 557-562.

Kementerian Kelautan dan Perikanan. 2018. Produktivitas Perikanan Indonesia. Jakarta.

Kordi, M.G.H. K, \& Tancung. B. A. (2007). Pengelolaan Kualitas Air dalam Budidaya Perairan. Penerbit Rineka Citra. Jakarta. $208 \mathrm{hlm}$

Mahyudin, K. 2010. Panduan Lengkap Agribisnis Patin. Penebar Swadaya, Jakarta, Indonesia.

Octo, C. 2013. Pemberian Pakan Campuran Pada Larva Ikan Patin [Tesis]. Bogor. Institut Pertanian Bogor.

Prastiwi, W., Santoso, L., dan Maharani, W. 2016. Pemberian Moina sp. Yang Diperkaya Tepung Ikan Untuk Meningkatkan Kelangsungan Hidup Dan Pertumbuhan Larva Ikan Lele (Clarias sp). Jurnal Rekayasa dan Teknologi Budidaya Perairan. Vol. 5(1) : 1-6.

Raharjo, E.I., Hasan, H., dan Darmawan, D. 2016. Pergantian Pakan Terhadap Pertumbuhan dan Kelangsungan Hidup Larva Ikan Gurami. Jurnal Ruaya. Vol. 4 (1) :13-17.

Rahmah, S., Kato, K., Yamamoto, S., Takii, K., Murata, O., dan Senoo, S. 2012. Improved Survival and Growth Performances with Photoperiod and Feeding Schedule Manipulation in Bagrid Catfish Mystus nemurus (Cuvier \& Valenciennes 1840) larvae. 
Journal Aquaculture Research 4 (5) : 501-508. DOI : 10.1111/j.13652109.2012.03253

Ramadhan, R., dan Yusanti, I.A. 2020. Studi Parameter Studi Kadar Nitrat Dan Fosfat Perairan Rawa Banjiran Desa Sedang Kecamatan Suak Tapeh Kabupaten Banyuasin. Jurnal Ilmu-ilmu Perikanan dan Budidaya Perairan. Vol 15(1) : $37-41$. DOI: http://dx.doi.org/10.31851/i ipbp.v15i1.4407

Srichanun, M., Tantikitti, C., V. Vatanukul, V., dan Musikarune, P. 2012. Digestive Enzyme Activity During Ontogenetic Development And Effect Of Live Feed In Green Catfish Larvae (Mystus Nemurus Cuv. \& Val.). Songklanasarin : Journal of Science and Technology. Vol. 34(3) : 247-254.
Supriyan, H., Harris, H., Haris, R. B. K., Yusanti, I. A., Sumantriyadi., dan Arumwati. 2020. Penambahan Probiotik Microbacter Alfaafa 11 Terhadap Pertumbuhan, Kelangsungan Hidup Dan FCR Pada Benih Ikan Patin Siam (Pangasius hypophthalmus). Aurelia Journal. Vol.1 No.2. Hlm :39-52.

Yuli, S., Harris, H., Yusanti, I. A. 2017. Tingkat Serangan Ektoparasit pada Ikan Patin (Pangasius hypopthalmus) yang Dibudidayakan dalam Keramba Jaring Apung di Sungai Musi Palembang. Jurnal Ilmu - ilmu Perikanan dan Budidaya Perairan. 12(2) : 50-58. DOI : http://dx.doi.org/10.31851/jipbp. v12i2.1473 